Article

\title{
Dehydration of sugars to 5-hydroxymethylfurfural and non-stoichiometric formic and levulinic acids over mesoporous Ta and Ta-W oxide solid acid catalysts
}

\author{
Bin Guo a, Lulu He ${ }^{\text {a }}$, Gangfeng Tang a , Li Zhang a, Lin Ye a, Bin Yue a,*, Shik Chi Edman Tsang b, \\ Heyong $\mathrm{He}^{\mathrm{a}, \#}$ \\ a Shanghai Key Laboratory of Molecular Catalysis and Innovative Materials, Collaborative Innovation Center of Chemistry for Energy Materials, \\ Department of Chemistry, Fudan University, Shanghai 200433, China \\ ${ }^{\mathrm{b}}$ Wolfson Catalysis Centre, Department of Chemistry, University of OXford, OXford OX1 3QR, UK
}

\section{A R T I C L E I N F O}

\section{Article history:}

Received 28 November 2019

Accepted 27 December 2019

Published 5 August 2020

\section{Keywords:}

Glucose

Fructose

HMF

Solid acid

Tantalum oxide

Ta-W oxide

\begin{abstract}
A B S T R A C T
A series of mesoporous Ta and Ta-W oxides have been prepared and employed as solid acid catalysts for the dehydration of fructose and glucose to 5-hydroxymethylfurfural (HMF). Solid state ${ }^{31} \mathrm{P}$ MAS NMR spectroscopic results using trimethylphosphine (TMP) as a probe molecule show that the acid strength and the ratio of Brönsted to Lewis acid sites increase gradually with the addition of tungsten in tantalum oxide. It is found that high sugar conversion and HMF selectivity are achieved over catalyst with relatively high ratios of Brönsted to Lewis acid sites. Unexpected stoichiometric excess of formic acid relative to levulinic acid can be observed mainly because of direct decomposition of fructose over Lewis acid sites. The addition of 2-butanol leads to the increase of sugars conversion and the HMF selectivity, especially for the catalyst with high ratio of Brönsted to Lewis acid sites. Among them, $\mathrm{Ta}_{7} \mathrm{~W}_{3}$ oxide catalyst shows $54 \% \mathrm{HMF}$ selectivity and good reusability with the addition of 2-butanol by extracting HMF from aqueous phase and removing humins deposed on the surface of the catalyst.
\end{abstract}

(c) 2020, Dalian Institute of Chemical Physics, Chinese Academy of Sciences. Published by Elsevier B.V. All rights reserved.

\section{Introduction}

With the growing concern about global warming along with the diminishing fossil fuel reserves, much attention has been paid to find new sustainable source of energy from renewable natural resources in recent decades. As the most abundant renewable feedstock, biomass has been regarded as an alternative carbon source for the production of fuel and fine chemicals. Biomass consists of carbohydrates, lignin and others. Carbohydrates are the most important fractions of biomass and the largest natural source of carbon [1]. Therefore, it makes carbohydrates a potential resource for the production of useful platform chemicals such as 5-hydroxymethylfufural (HMF), furfural and levulinic acid [1-4]. Among them, HMF and its derivatives can be converted to various important chemicals, such as 2,5-furandicarboxylic acid for the replacement of terephthalic acid in the polyethylene terephthalate industry and adipic acid used as monomer in the nylon industry $[5,6]$.

Synthesis of HMF from fructose can be realized over Brönsted acid sites more easily than from glucose because the

\footnotetext{
* Corresponding author. Tel: +86-21-31243916; E-mail: yuebin@fudan.edu.cn

\# Corresponding author. E-mail: heyonghe@fudan.edu.cn

This work was supported by the National Natural Science Foundation of China $(21673046,91645201)$.

DOI: S1872-2067(19)63519-9 | http://www.sciencedirect.com/science/journal/18722067 | Chin. J. Catal., Vol. 41, No. 8, August 2020
} 
reactivity of fructose (ketose) is higher than that of glucose (aldose) in aqueous solution. Thus, the dehydration of fructose to HMF over homogeneous and heterogeneous acidic catalysts has been extensively studied in aqueous [7], multiphase systems $[4,8-11]$, or ionic liquids $[12,13]$. Previous studies have shown that the direct dehydration of glucose to HMF leads to low selectivity to HMF [14]. The transformation process of glucose to HMF is rather complicated due to a number of parallel reactions [15]. As shown in Scheme 1, those parallel reactions include dehydration of glucose to cellobiose and levoglucosan, polymerization of unreacted glucose or formed fructose with reaction products containing aldehyde group such as HMF and furfural over acid sites to form polymers such as humins $[16,17]$, and rehydration of formed HMF to levulinic acid and formic acid in aqueous system [18]. From the mechanistic point of view, the yield of HMF can be increased significantly by initial isomerization of glucose to fructose over Lewis acid sites in tandem with dehydration of fructose over Brönsted acid sites [19].

Many attempts have been made to improve the activity of Lewis acid catalysts for isomerization of glucose to fructose before the sequent dehydration of fructose to HMF over Brönsted acid. In particular, a combination of $\mathrm{CrCl}_{2}$ and ionic liquids showed the optimal HMF yield of near $70 \%$ [20]. $\mathrm{CrCl}_{2}$ was used as Lewis acid catalyst which promoted the isomerization of glucose to fructose followed by a dehydration to HMF. Moreover, similar homogeneous catalysts have also been studied, such as $\mathrm{AlCl}_{3}$ combined with $\mathrm{HCl}[8,14]$, lanthanide-based metallic salts in biphasic systems [21], and $\mathrm{Zr}(0) \mathrm{Cl}_{2} / \mathrm{CrCl}_{3}$ catalyst in $\mathrm{N}, \mathrm{N}$-dimethyl acetamide solvent containing $\mathrm{LiCl}$ [22]. Other catalysts such as $\mathrm{ZnCl}_{2}$ [23], $\mathrm{CrCl}_{3}$ [24] and $\mathrm{WCl}_{3}$ [25] were also used in aqueous catalytic system. However, the application of ionic liquids and metallic salts with mineral acids have many disadvantages, such as high cost of ionic liquids, corrosion of mineral acids, or difficult recovery of the catalysts from the reaction mixture. For industrial applications, it would be preferable to use heterogeneous catalysts in the reaction of

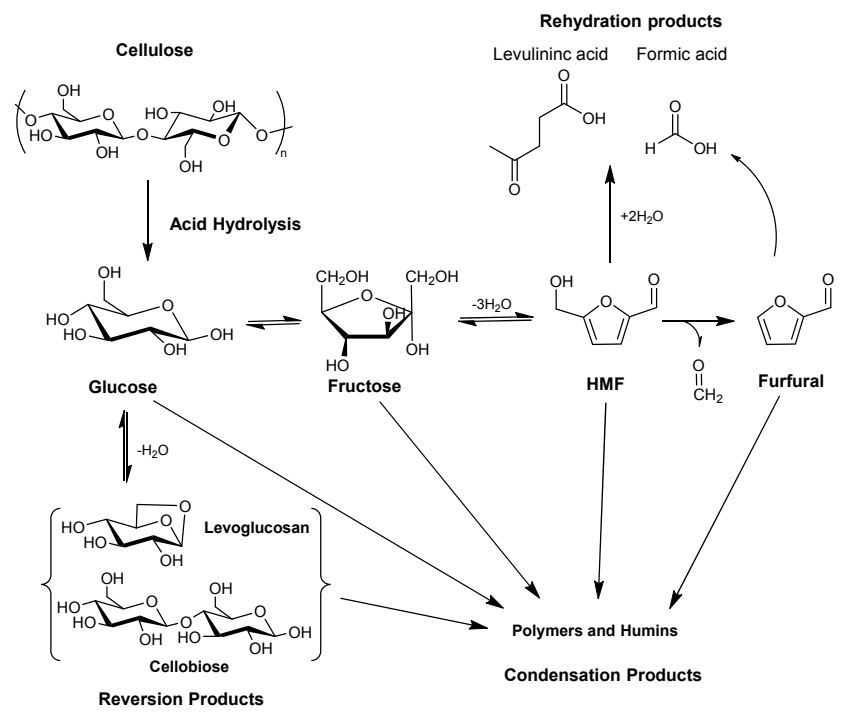

Scheme 1. Reaction pathway for conversion of saccharides to HMF [26]. glucose to HMF.

Solid acid catalysts based on oxides of $\mathrm{Nb}$ [26-31], Ta [32-34], Sn [35,36], Zr [37] and Ti [38-41] have been employed in the synthesis of HMF. Among them, niobic acid $\left(\mathrm{Nb}_{2} \mathrm{O}_{5} \cdot n \mathrm{H}_{2} \mathrm{O}\right)$ [27] and tantalic acid $\left(\mathrm{Ta}_{2} \mathrm{O}_{5} \cdot \mathrm{nH}_{2} \mathrm{O}\right)$ [32] are both considered as water-tolerant solid acids which display good activity in the dehydration of glucose to HMF. It was reported that the yield of HMF was close to $50 \%$ in water/2-butanol biphasic system at $160{ }^{\circ} \mathrm{C}$ over phosphoric acid treated niobium and tantalum compounds [32]. Moreover, it was proposed that synergistic effect of protonated phosphate groups with nearby metal Lewis acid sites in the dehydration of glucose achieves a high selectivity to HMF [42]. However, the catalyst with excessive Lewis acid sites leads to unselective glucose transformation to side products $[16,24,42,43]$.

Herein, we have prepared a series of mesoporous Ta-W oxides with different ratios of $\mathrm{Ta} / \mathrm{W}$ and aimed to modulate the acidic properties of the catalysts suitable for the dehydration of fructose and glucose in aqueous and 2-butanol/ $\mathrm{H}_{2} \mathrm{O}$ system. The role of the density and strength of Lewis and Brönsted acid sites on different Ta-W oxides in catalytic transformation of glucose and fructose has been investigated in details by using MAS NMR techniques. Moreover, the promotional effect of 2-butanol in the reaction media on the catalytic performance has been discussed.

\section{Experimental}

\subsection{Catalyst preparation}

Mesoporous tantalum oxide was synthesized via a neutral templating route, in a similar procedure to the synthesis of mesoporous niobium oxide previously reported [26,44]. The solution containing $2.56 \mathrm{~g}$ of triblock copolymer P123 $\left(\mathrm{EO}_{20} \mathrm{PO}_{70} \mathrm{EO}_{20}\right.$, Sigma Aldrich), $20 \mathrm{~g}$ of $n$-propanol, and $5.01 \mathrm{~g}$ (14 mmol) of tantalum pentachloride $\left(\mathrm{TaCl}_{5}, 99+\%\right.$, Strem Chemicals) was stirred vigorously at room temperature for 30 min, then $2 \mathrm{~g}$ of de-ionized water was added with further stirring for ca. $2 \mathrm{~h}$. The resulting sol was gelled on a glass plate at $40{ }^{\circ} \mathrm{C}$ under controllable humidity of $c a .45 \%$ for $5 \mathrm{~d}$. The aged gel sample was calcined at $450{ }^{\circ} \mathrm{C}$ for $5 \mathrm{~h}$ in air to remove the block copolymer surfactant.

Mesoporous Ta-W oxides with different Ta/W molar ratio, $\mathrm{Ta}_{9} \mathrm{~W}_{1}, \mathrm{Ta}_{7} \mathrm{~W}_{3}$ and $\mathrm{Ta}_{5} \mathrm{~W}_{5}$, were synthesized by dissolving 2.56 $\mathrm{g}$ of P123, $20 \mathrm{~g}$ of n-propanol, desired amount of $\mathrm{WCl}_{6}$ (99+\%, Strem Chemicals) and $\mathrm{TaCl}_{5}$ (total of $12 \mathrm{mmol}$ of metal chloride) with vigorous stirring at room temperature for $30 \mathrm{~min}$. Then $1.08 \mathrm{~g}$ of de-ionized water was added with further stirring for ca. $2 \mathrm{~h}$. The resulting sol was gelled on a glass plate at $40{ }^{\circ} \mathrm{C}$ under controllable humidity of $c a .45 \%$ for $5 \mathrm{~d}$. The aged gel samples were calcined at $450{ }^{\circ} \mathrm{C}$ for $5 \mathrm{~h}$ in air to remove the surfactant.

\subsection{Catalyst characterization}

The textural properties of the catalysts were evaluated from nitrogen adsorption-desorption isotherms at $-196{ }^{\circ} \mathrm{C}$ using a 

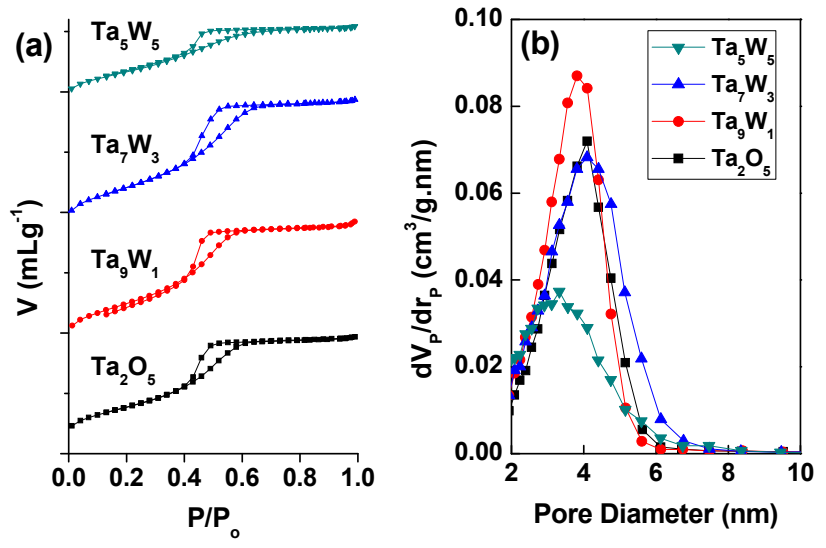

Fig. 1. $\mathrm{N}_{2}$ adsorption-desorption isotherms (a) and pore size distributions (b) of $\mathrm{Ta}_{2} \mathrm{O}_{5}$ and Ta-W oxides.

Quantachrome Quadrasorb SI apparatus. The samples were degassed at $250{ }^{\circ} \mathrm{C}$ for $3 \mathrm{~h}$ before measurement. The surface areas were calculated using the BET method. Pore size distribution curves were derived from the desorption branches of isotherms and calculated by the BJH model. The X-ray diffraction (XRD) patterns were recorded on a Bruker D8 Advances $\mathrm{X}$-ray diffractometer using $\mathrm{Cu}$-K $\alpha$ radiation with a voltage of 40 $\mathrm{kV}$ and a current of $40 \mathrm{~mA}$. Solid-state nuclear magnetic resonance (NMR) spectra were obtained on a Bruker Avance III 400 spectrometer. High-power ${ }^{1} \mathrm{H}$ decoupling ${ }^{31} \mathrm{P}$ magic angle spinning (MAS) NMR spectra were acquired at $161.9 \mathrm{MHz}$ using a $30^{\circ}$ pulse and a recycle delay of $15 \mathrm{~s}$ at a spinning rate of 12 $\mathrm{kHz}$ with $4 \mathrm{~mm}$ zirconia rotor. $\mathrm{NH}_{4} \mathrm{H}_{2} \mathrm{PO}_{4}$ was used as a standard sample for chemical shift referencing $(0.81 \mathrm{ppm})$ and the external intensity standard to quantify the signal. After pretreating at $300{ }^{\circ} \mathrm{C}$ for 90 min under vacuum, powdered sample in glass tube was immersed in liquid nitrogen to introduce a certain amount of probe molecule trimethylphosphine (TMP). Then, TMP-adsorbed sample was transferred in a glovebox and packed into a rotor under dried $\mathrm{N}_{2}$.

\subsection{Catalytic activity test}

The catalytic dehydration of fructose or glucose was carried out in a $50 \mathrm{~mL}$ autoclave with continuous magnetic stirring and heated in a temperature controlled oil bath. The reaction was performed by using $0.1 \mathrm{~g}$ of catalyst and $5 \mathrm{~mL}$ of $2 \mathrm{wt} \%$ of substrate. The reactor was raised to certain temperature and held for a given reaction time. After reaction, the reactor was quenched immediately with cold water. In both aqueous and 2-butanol $/ \mathrm{H}_{2} \mathrm{O}$ systems the mixture was centrifuged and the

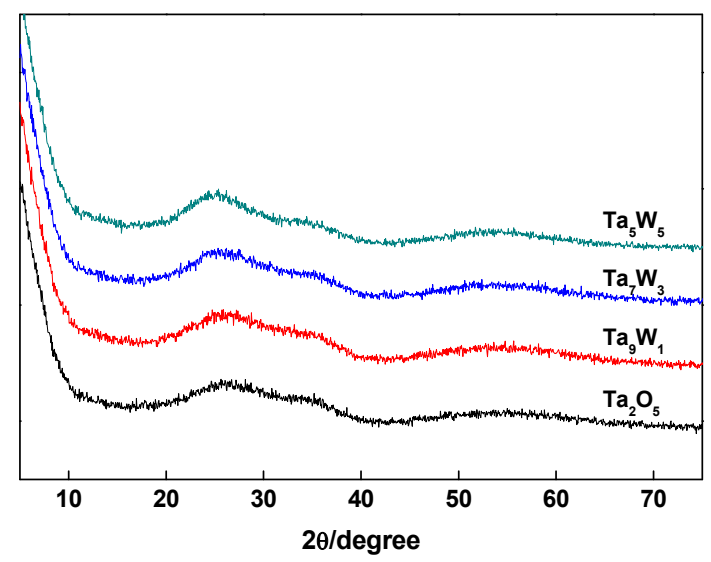

Fig. 2. Powder XRD patterns for $\mathrm{Ta}_{2} \mathrm{O}_{5}$ and $\mathrm{Ta}-\mathrm{W}$ oxides.

liquid samples were filtered through a $0.25 \mu \mathrm{m}$ filter before analysis. Liquid samples were analyzed by HPLC equipped with refractive index and UV-Vis detectors at wavelength of $284 \mathrm{~nm}$ with a Biorad@ Aminex HPX-87H sugar column. The mobile phase was $0.005 \mathrm{M} \mathrm{H}_{2} \mathrm{SO}_{4}$ aqueous solution flowing at a rate of $0.6 \mathrm{~mL} \mathrm{~min}^{-1}$ at $35^{\circ} \mathrm{C}$

\section{Results and discussion}

\subsection{Physico-chemical properties of the catalysts}

Nitrogen adsorption-desorption isotherms and the pore size distribution of the Ta-W oxides are shown in Fig. 1 and Table 1. All the samples show the type IV isotherms with a clear hysteresis loop. Except $\mathrm{Ta}_{5} \mathrm{~W}_{5}$ oxide, $\mathrm{Ta}_{2} \mathrm{O}_{5}, \mathrm{Ta}_{9} \mathrm{~W}_{1}$ and $\mathrm{Ta}_{7} \mathrm{~W}_{3}$ have the similar BET specific surface areas of $\sim 170 \mathrm{~m}^{2} \mathrm{~g}^{-1}$ and pore volume of $\sim 4.0 \mathrm{~cm}^{3} \mathrm{~g}^{-1}$. The BET specific surface area and pore volume of $\mathrm{Ta}_{5} \mathrm{~W}_{5}$ decreases due to the deteriorated porosity at high tungsten content. Wide-angle powder XRD patterns illustrated in Fig. 2 only show broad diffractions, which reveal an amorphous nature of all Ta-W oxides.

Considering the significant role of the catalyst acidity in the titled reaction, an effective characterization method of acidity should be found. $\mathrm{NH}_{3}$ temperature programmed desorption ( $\mathrm{NH}_{3}$-TPD) and infrared spectroscopy of pyridine adsorption (pyridine-IR) have been generally adopted. However, it is difficult to distinguish between Brönsted acid and Lewis acid and to acquire the subtle differences in the acid strength distribution by using $\mathrm{NH}_{3}$-TPD, and to study acid density quantitatively by using pyridine-IR. 31P MAS NMR spectroscopy with TMP as the probe molecule has the advantage of distinguishable and assignable peaks which may provide comprehensive information

Table 1

Physico-chemical properties of the catalysts.

\begin{tabular}{|c|c|c|c|c|c|c|c|c|}
\hline \multirow{2}{*}{$\frac{\text { Catalyst }}{\mathrm{Ta}_{2} \mathrm{O}_{5}}$} & \multirow{2}{*}{$\frac{S_{\mathrm{BET}} / \mathrm{m}^{2} \mathrm{~g}^{-1}}{170}$} & \multirow{2}{*}{$\begin{array}{c}\text { Pore volume } / \mathrm{cm}^{3} \mathrm{~g}^{-1} \\
0.20\end{array}$} & \multirow{2}{*}{$\frac{\text { Pore diameter } / \mathrm{nm}}{4.0}$} & \multicolumn{2}{|c|}{ Brönsted acid/ $\mu \mathrm{mol} \mathrm{g}-1$} & \multicolumn{2}{|c|}{ Lewis acid $/ \mu \mathrm{mol} \mathrm{g}-1$} & \multirow{2}{*}{$\frac{\mathrm{B} / \mathrm{L}}{0.27}$} \\
\hline & & & & 88 & Weak & 330 & Medium & \\
\hline $\mathrm{Ta}_{9} \mathrm{~W}_{1}$ & 168 & 0.20 & 3.9 & 81 & & 262 & $\downarrow$ & 0.31 \\
\hline $\mathrm{Ta}_{7} \mathrm{~W}_{3}$ & 169 & 0.20 & 4.0 & 99 & $\downarrow$ & 148 & Strong & 0.67 \\
\hline $\mathrm{Ta}_{5} \mathrm{~W}_{5}$ & 121 & 0.11 & 3.3 & 78 & Strong & 250 & Weak & 0.31 \\
\hline
\end{tabular}




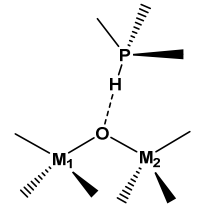

(a)

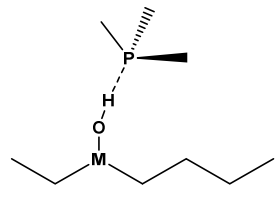

(b)

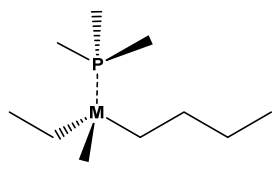

(c)
Scheme 2. Three types of adsorbed trimethylphosphine. (a) Chemisorbed on Brönsted acid sites; (b) physisorbed on hydroxyls (hydrogen bonding interaction); (c) chemisorbed on Lewis acid centers [50].

on the acid type, strength distribution, and relevant density [45-48]. Herein, the acid properties of Ta-W oxides were evaluated by ${ }^{31} \mathrm{P}$ MAS NMR spectroscopy using TMP as a probe molecule. Scheme 2 shows three types of adsorbed TMP. TMP tends to form protonated adduct on Brönsted acid sites, giving rise to ${ }^{31} \mathrm{P}$ resonances in a rather narrow range of -2 to $-5 \mathrm{ppm}$ [49]. The wide range of chemical shift from -20 to $-60 \mathrm{ppm}$ is assigned to TMP on Lewis acid sites, which implies the adsorbed TMP is more sensitive to the strength of Lewis acid than that of Brönsted acid [50]. The physisorbed TMP commonly gives rise to ${ }^{31} \mathrm{P}$ resonance at $\sim-62 \mathrm{ppm}[48]$.

The ${ }^{31} \mathrm{P}$ MAS NMR spectra of $\mathrm{Ta}_{2} \mathrm{O}_{5}$ and $\mathrm{Ta}-\mathrm{W}$ oxides are shown in Fig. 3. The acidic characterization results are summarized in Table 1 . The broad peak at $62 \sim 68 \mathrm{ppm}$ was observed on all $\mathrm{Ta}_{2} \mathrm{O}_{5}$ and $\mathrm{Ta}-\mathrm{W}$ oxides, which could be assigned to trimethylphosphine oxide (TMPO) interacting with Brönsted acid sites [51]. The existence of TMPO is possibly due to the oxidation of TMP on the surface of $\mathrm{Ta}_{2} \mathrm{O}_{5}$ and $\mathrm{Ta}-\mathrm{W}$ oxides [26]. The 31P chemical shifts of protonated TMPO (formed on Brönsted acid sites) tended to move downfield from $62.4 \mathrm{ppm}\left(\mathrm{Ta}_{2} \mathrm{O}_{5}\right)$ to $67.8 \mathrm{ppm}\left(\mathrm{Ta}_{5} \mathrm{~W}_{5}\right)$ with increasing tungsten content. It reveals that the acid strength of Brönsted acid sites is enhanced by addition of tungsten in $\mathrm{Ta}_{2} \mathrm{O}_{5}$ since higher chemical shift values indicate higher protonic acid strength. The addition of tungsten

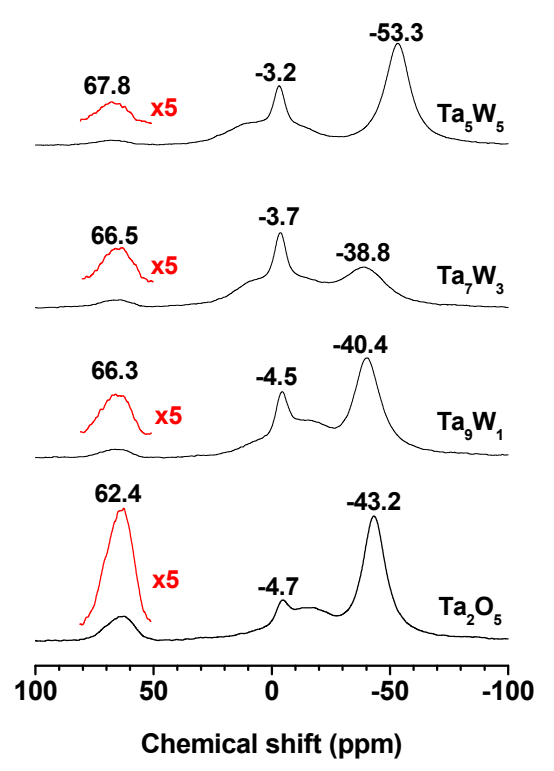

Fig. 3. ${ }^{31} \mathrm{P}$ MAS NMR spectra of $\mathrm{Ta}_{2} \mathrm{O}_{5}$ and $\mathrm{Ta}-\mathrm{W}$ oxides adsorbed with TMP. in tantalum oxide results in partial replacement of $\mathrm{Ta}^{5+}$ ions by higher-valence $\mathrm{W}^{6+}$ ions, leading to enhancement of the acidic strength of bridged hydroxyl groups (Ta- $(\mathrm{OH})-\mathrm{W})$ which act as Brönsted acid sites. This is in agreement with the results of $\mathrm{Nb}-\mathrm{W}$ oxides [52]. On the other hand, Lewis acid sites in tantalum oxide are mostly generated from $\mathrm{TaO}_{4}$ tetrahedra and highly distorted $\mathrm{TaO}_{6}$ octahedra. For $\mathrm{Ta}_{2} \mathrm{O}_{5}, \mathrm{Ta}_{9} \mathrm{~W}_{1}$ and $\mathrm{Ta}_{7} \mathrm{~W}_{3}$ oxides, the replacement of $\mathrm{Ta}^{5+}$ ions by $\mathrm{W}^{6+}$ ions decreases the electron densities of $\mathrm{Ta}^{5+}$ ions, the ${ }^{31} \mathrm{P}$ chemical shifts of TMP on Lewis acid sites tend to shift to low field (from $-43.2 \mathrm{ppm}$ on $\mathrm{Ta}_{2} \mathrm{O}_{5}$ to $-38.8 \mathrm{ppm}$ on $\mathrm{Ta}_{7} \mathrm{~W}_{3}$ ) with increasing tungsten content. Since the decrease of Lewis acid sites from $330 \mu \mathrm{mol} \mathrm{g}^{-1}$ of $\mathrm{Ta}_{2} \mathrm{O}_{5}$ to $148 \mu \mathrm{mol} \mathrm{g}{ }^{-1}$ of $\mathrm{Ta}_{7} \mathrm{~W}_{3}$ oxide, it can be anticipated that the addition of tungsten in tantalum oxide generates more perfect octahedra. However, the ${ }^{31} \mathrm{P}$ MAS NMR results show an increasing amount of Lewis acid sites on $\mathrm{Ta}_{5} \mathrm{~W}_{5}$ oxide with chemical shifts of $-53.3 \mathrm{ppm}$. This is mainly caused by formation of amorphous surface polytungstate species with high amount of tungsten which act as weak Lewis acid compared with that on tantalum oxide [52,53]. In summary, the ratios of Brönsted to Lewis acid sites over Ta and Ta-W oxides catalysts has the order of $\mathrm{Ta}_{7} \mathrm{~W}_{3}>\mathrm{Ta}_{9} \mathrm{~W}_{1} \sim \mathrm{Ta}_{5} \mathrm{~W}_{5}>\mathrm{Ta}_{2} \mathrm{O}_{5}$, while $\mathrm{Ta}_{5} \mathrm{~W}_{5}$ oxide has weaker Lewis acidity and stronger Brönsted acidity than Tag $\mathrm{W}_{1}$ oxide.

\subsection{Dehydration of fructose and glucose in aqueous phase}

\subsubsection{Dehydration of fructose and glucose over sulfuric acid}

Fig. 4 shows the dehydration of fructose and glucose over SA at $140{ }^{\circ} \mathrm{C}$ in aqueous phase. In Fig. 4(a), mineral acid SA shows extremely high catalytic activity on fructose dehydration with $96 \%$ fructose conversion after 120 min reaction. Meanwhile, both selectivities to levulinic acid (LA) and formic acid (FA) increase with increasing reaction time to almost $49 \%$ after $240 \mathrm{~min}$, accompanied with the decrease of HMF selectivity from $56 \%$ to near zero. Based on the experimental data and change trends on selectivity to HMF and the acids, it indicates that formed HMF is almost transformed into levulinic acid and formic acid over Brönsted acid, SA, through a tandem pathway including dehydration of fructose to HMF and rehydration of HMF to levulinic acid and formic acid. On the other hand, when glucose was employed as the substrate, only $12 \%$ of glucose conversion was achieved even after 360 min reaction in the presence of SA (Fig. 4(b)). It suggests that the dehydration of glucose is very difficult to proceed over sulfuric acid which has no Lewis acidity. Also, no HMF was observed, possibly due to low yield of HMF and easy hydration of HMF with mineral acid in aqueous system. However, summation of the selectivity to the acid products shows that only $\sim 26 \%$ of converted glucose is transformed to levulinic acid and formic acid. It means that most of glucose is transformed to side products such as cellobiose and levoglucosan over Brönsted acid (Scheme 1).

\subsubsection{Dehydration of fructose over Ta and Ta-W oxide catalysts in aqueous phase}

The fructose conversion and the selectivities to HMF, formic acid and glucose during dehydration of fructose over various 

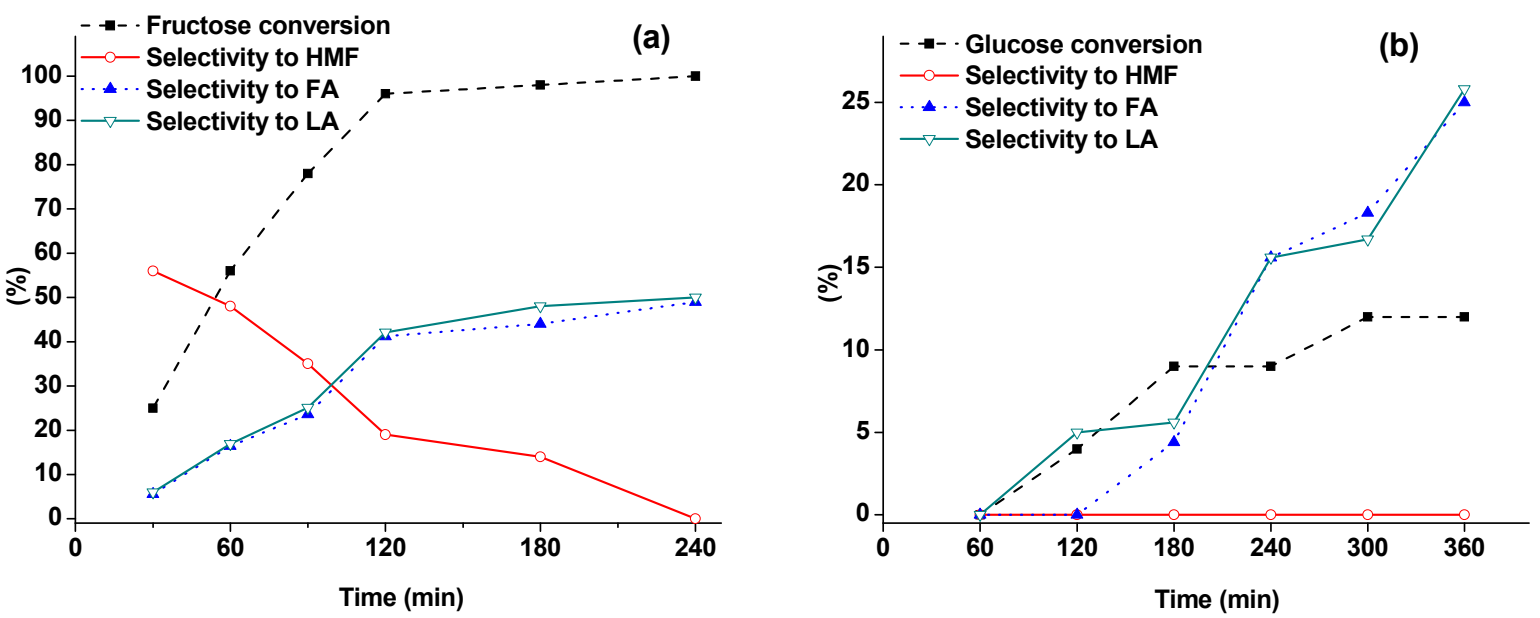

Fig. 4. Dehydration of fructose (a) and glucose (b) with sulfuric acid in aqueous phase. Reaction conditions: $0.1 \mathrm{~g}$ of catalyst, $5 \mathrm{~mL}$ of 2 wt $\%$ sugar solution, $140{ }^{\circ} \mathrm{C}$ with stirring

Ta and Ta-W oxide catalysts are shown in Fig. 5. Notably, the selectivities to these main products are less than $100 \%$ due to the existence of humins which cannot be detected by HPLC. All Ta and Ta-W oxide catalysts show high catalytic activity on dehydration of fructose, with $>95 \%$ fructose conversion at 140 ${ }^{\circ} \mathrm{C}$ after $360 \mathrm{~min}$ reaction (Fig. 5(a)). At $60 \mathrm{~min}$ reaction, the fructose conversion over $\mathrm{Ta}_{2} \mathrm{O}_{5}$ reaches a value of $55 \%$ and is comparable with that of homogenous acid catalyst SA (56\%), whereas all three $\mathrm{Ta}-\mathrm{W}$ oxide catalysts demonstrate higher fructose conversion ( $\sim 70 \%)$. Notably, all three Ta-W oxide catalysts have higher ratio of Brönsted to Lewis acid sites and stronger Brönsted acidity than $\mathrm{Ta}_{2} \mathrm{O}_{5}$ (Table 1), indicating the occurrence of fructose dehydration is dominated under the role of Brönsted acid. This is consistent with the proposed mechanism in literature $[4,24,54,55]$.

The selectivity to HMF over different catalysts is shown in Fig. 5(b). Similar trends are observed over all catalysts. The HMF selectivity firstly increases then slightly decreases with increasing reaction times, owing to increasing of side reactions such as degradation of HMF and condensation to soluble polymers and humins $[15,16,24,42]$. The HMF selectivity reaches a maximum value over $\mathrm{Ta}_{2} \mathrm{O}_{5}$ after 240 min. On the other hands, the HMF selectivity over $\mathrm{Ta}_{9} \mathrm{~W}_{1}, \mathrm{Ta}_{7} \mathrm{~W}_{3}$ and $\mathrm{Ta}_{5} \mathrm{~W}_{5}$ oxides with relatively higher ratios of Brönsted to Lewis acid sites and stronger Brönsted acidity achieve their maximum value at shorter reaction time ( $<200 \mathrm{~min})$.

The selectivity to formic acid in Fig. 5(c) is significantly higher than that of levulinic acid, whereas the selectivity to LA over all catalysts is not higher than 3\% (not shown). Also, Fig. 5(c) shows excess formation of FA is obvious even in the early reaction stage when humins formation and HMF rehydration are still not prevalent. It is well known that an equimolar of LA and FA should be obtained if both of them are produced only by HMF rehydration [56]. Therefore, the excess formation of FA possibly originates from direct decomposition of fructose or a fructose-derived intermediate. Since the stoichiometric equimolar formation of FA and LA occurs via a typical Brönsted acid catalyzed path of HMF rehydration over pure SA, the observed excess formed FA in Fig. 5(c) is supposed to be cata- lyzed by Lewis acid sites on Ta and Ta-W oxides catalysts. Results in Fig. 5(c) show that relatively high FA selectivities were achieved over $\mathrm{Ta}_{2} \mathrm{O}_{5}$ and $\mathrm{Ta}_{9} \mathrm{~W}_{1}$ oxides with high Lewis acid density, whereas low FA selectivity over $\mathrm{Ta}_{7} \mathrm{~W}_{3}$ oxide. However, the lowest FA selectivity was achieved over Ta5 $\mathrm{W}_{5}$ oxides, due to the weakest Lewis acidity and strongest Brönsted acidity.

Fig. 5(d) shows the selectivity to glucose over Ta and Ta-W oxides. This suggests that the fructose-glucose isomerization is reversible and occurs over Lewis acid since no glucose was produced from fructose over pure SA. However, all of the selectivities to glucose from fructose over Ta and Ta-W oxides are not high than $3 \%$, due to the equilibrium of fructose transformation shifting to fructose dehydration rather than fructose-glucose isomerization.

\subsubsection{Dehydration of glucose over Ta and Ta-W oxide catalysts in aqueous phase}

The dehydration of glucose to HMF in aqueous phase was also investigated (Fig. 6). Fig. 6(a) shows the glucose conversion as function of reaction time over the Ta and Ta-W oxides catalysts. Higher glucose conversion is achieved over $\mathrm{Ta}_{7} \mathrm{~W}_{3}$ oxide with high ratios of Brönsted to Lewis acid sites, though the discrepancy of glucose conversion over Ta and Ta-W oxide catalysts is insignificant. It is clear that the conversions of glucose over all catalysts are relatively lower than that of fructose due to the lower reactivity of glucose than that of fructose. As mentioned above, the dehydration of glucose to HMF is a tandem reaction including isomerization of glucose to fructose and subsequent fructose dehydration to HMF. Hence, the selectivity to fructose is related with the balance of isomerization and dehydration.

As shown in Fig. 6(b), the selectivity to fructose achieves the highest value at the early reaction stage over all Ta and Ta-W oxides and then decreases with increasing reaction time. Higher fructose selectivity was obtained over $\mathrm{Ta}_{2} \mathrm{O}_{5}$ and $\mathrm{Ta}_{9} \mathrm{~W}_{1}$ oxides which have lower ratios of Brönsted to Lewis acid sites compared to $\mathrm{Ta}_{7} \mathrm{~W}_{3}$ xide. This is in agreement with the results reported by Dumesic et al. $[14,15,57]$ and Nijhuis et al. $[42,58]$, 

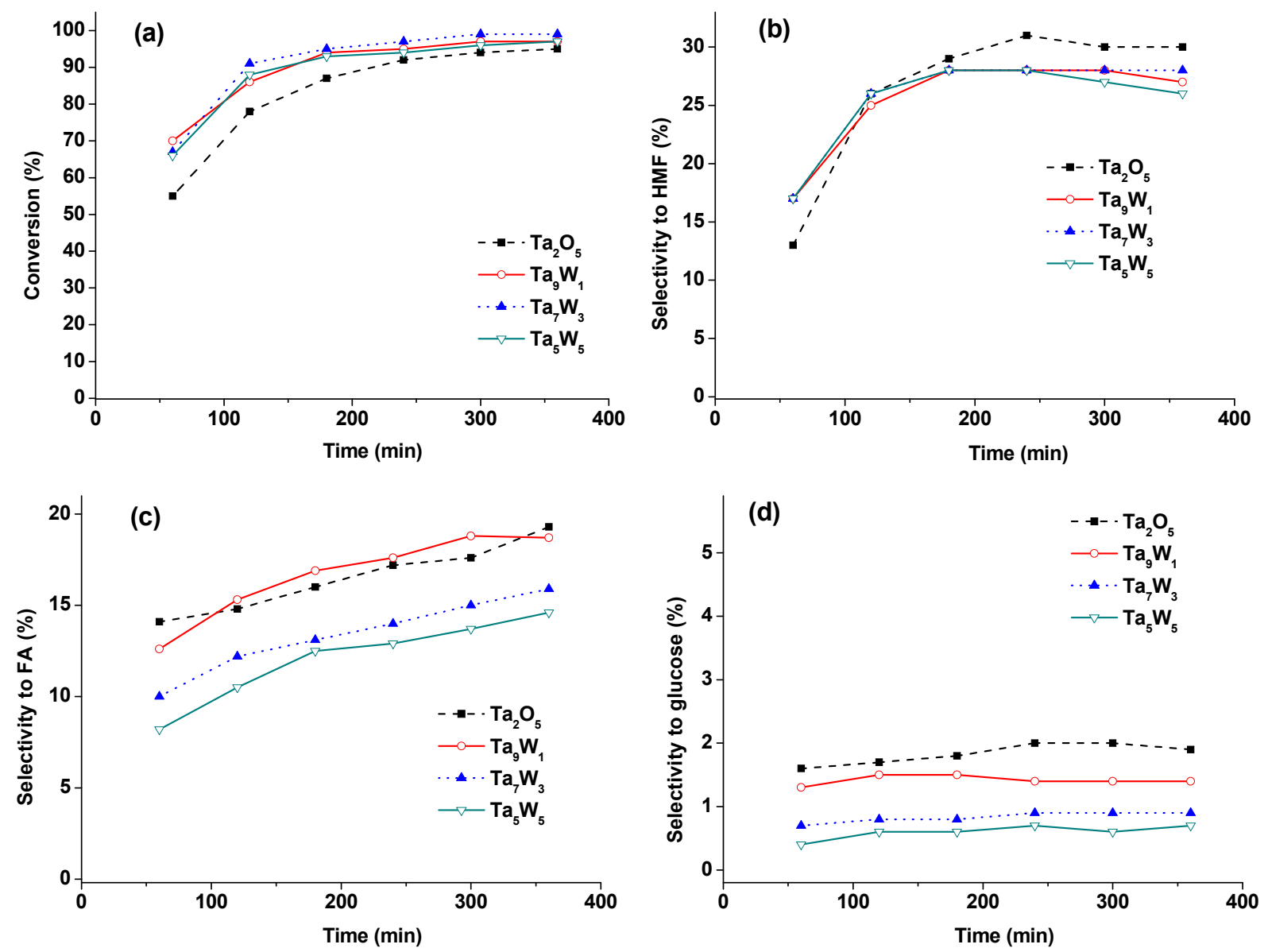

Fig. 5. Fructose conversion (a), selectivities to HMF (b), formic acid (c), and glucose (d) versus reaction time over Ta and Ta-W oxide catalysts. Reaction conditions: $0.1 \mathrm{~g}$ of catalyst, $5 \mathrm{~mL}$ of $2 \mathrm{wt} \%$ fructose solution, $140{ }^{\circ} \mathrm{C}$ with stirring.

where they found that the glucose-fructose isomerization occurred under the role of Lewis acid sites. However, the fructose selectivity over Ta5 $\mathrm{W}_{5}$ oxide is low in comparison with $\mathrm{Ta}_{9} \mathrm{~W}_{1}$ oxide, even though both catalysts have the same ratios of Brönsted to Lewis acid sites. It is possibly due to the existence of stronger Brönsted acid sites on $\mathrm{Ta}_{5} \mathrm{~W}_{5}$ oxide than that of $\mathrm{Ta}_{9} \mathrm{~W}_{1}$ oxide which benefits the subsequent fructose dehydration process.

The highest selectivity to HMF (47\%) from glucose was achieved over $\mathrm{Ta}_{7} \mathrm{~W}_{3}$ and $\mathrm{Ta}_{9} \mathrm{~W}_{1}$ oxide catalysts (Fig. 6(c)), which is much higher than that from fructose $(28 \%)$ over Ta-W oxides. With regard to dehydration of glucose, the concentration of formed fructose keeps low via a tandem reaction including continuous formation of fructose from glucose isomerization and subsequent dehydration of fructose to HMF, which minimizes side-reaction such as cross-polymerization of fructose and HMF or condensation of fructose on Lewis acid sites. The selectivity to HMF decrease as follows: $\mathrm{Ta}_{7} \mathrm{~W}_{3} \sim \mathrm{Ta}_{9} \mathrm{~W}_{1}>$ $\mathrm{Ta}_{2} \mathrm{O}_{5}>\mathrm{Ta}_{5} \mathrm{~W}_{5}$. This is consistent with the trend of the ratios of Brönsted to Lewis acid sites over various Ta-W oxides catalysts, except for $\mathrm{Ta}_{5} \mathrm{~W}_{5}$ oxide catalyst. The selectivity to HMF over $\mathrm{Ta}_{5} \mathrm{~W}_{5}$ oxide is lower than that over $\mathrm{Ta}_{9} \mathrm{~W}_{1}$ oxide even though they have the same ratio of Brönsted to Lewis acidity, which is possibly ascribed to the side reactions such as unselective de- hydration of glucose and rehydration of HMF over strong Brönsted acid sites on TasW5 $[15,16,24,42,58]$.

As shown in Fig. 6(d), the selectivities to FA over all Ta-W oxides catalysts are rather lower than those from fructose dehydration, which is in consistent with the observation of higher selectivity to HMF from glucose than fructose. As discussed above, it is convincible that the formation of excess FA is caused by direct decomposition of fructose under the role of Lewis acid. As for dehydration of glucose, continuous formation of fructose from glucose isomerization accompanied with dehydration of fructose to HMF keeps the concentration of fructose relatively low, which minimizes side reactions and excess FA. The selectivity to FA over all Ta-W oxides catalysts increases with reaction time from $\sim 5 \%$ to $\sim 12 \%$ and no significant discrepancy of FA selectivity is observed for all Ta-W oxides catalysts. Thus, the formation of excess FA from glucose is more likely originated from decomposition of formed fructose. Based on the results in Fig. 5(c) and Fig. 6(d), we have proposed a possible pathway responsible for the formation of excess FA from fructose and glucose in Scheme 3.

Brönsted acidity and Lewis acidity plays different roles in the dehydration of glucose and fructose to HMF in aqueous phase. Lewis acid is necessary for the effective dehydration of glucose to HMF, since the activation of glucose molecule occurs 

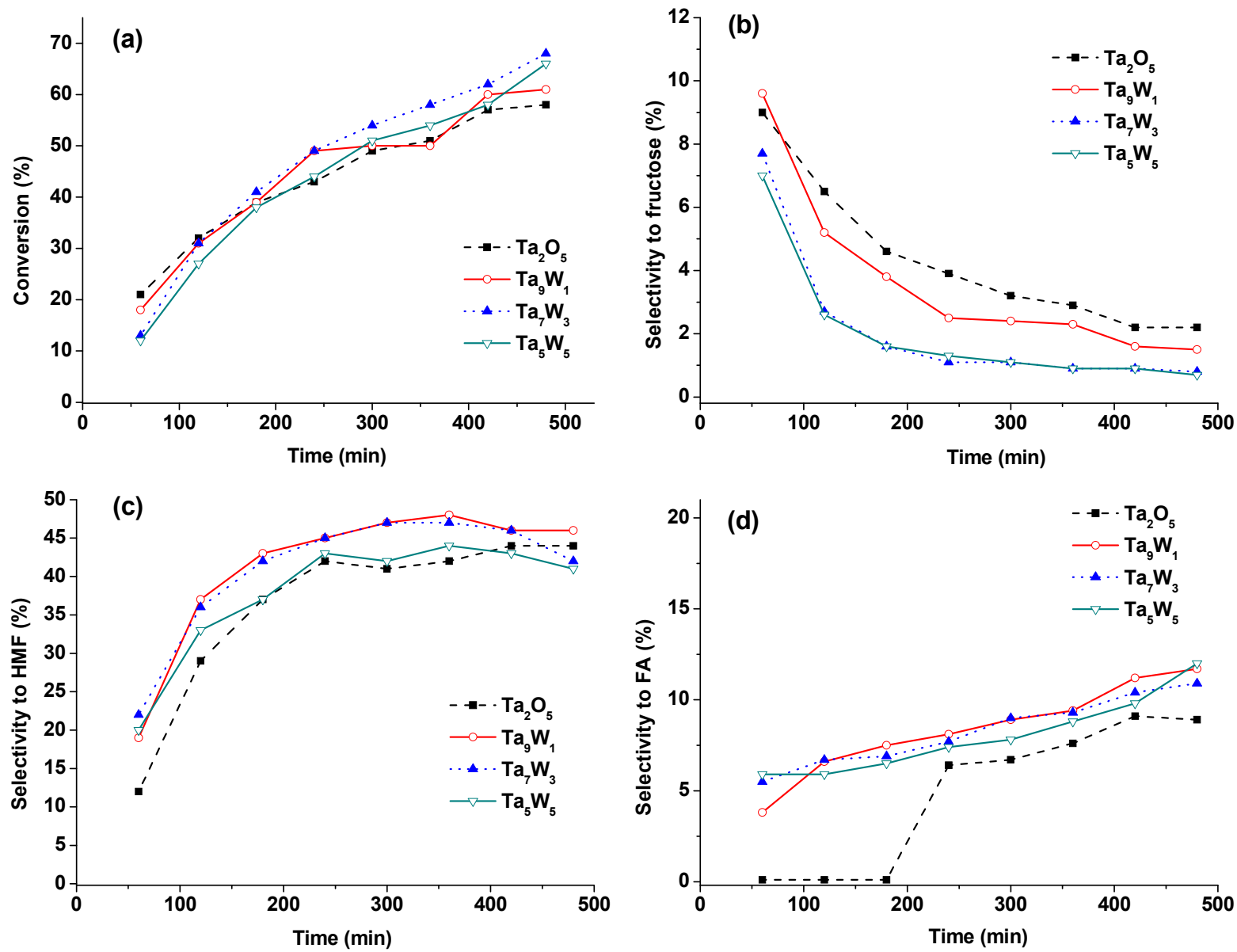

Fig. 6. Glucose conversion (a), selectivities to fructose (b), HMF (c), and formic acid (d) versus reaction time over Ta and Ta-W oxide catalysts. Reaction conditions: $0.1 \mathrm{~g}$ of catalyst, $5 \mathrm{~mL}$ of $2 \mathrm{wt} \%$ glucose solution, $140^{\circ} \mathrm{C}$ with stirring.

preferentially over Lewis acid sites. On the other hand, the second step of fructose dehydration to HMF is prevalent under the role of Brönsted acid. However, the correlation of the catalytic activity and surface acidity over various Ta-W oxides catalysts could be diminished by uncontrollable side reactions which are favored in aqueous catalytic system, especially when fructose is a starting material. It is noteworthy that approximately $45 \%$ of glucose is transformed into humins which cannot be detected by HPLC and GC-MS. In general, humins are formed by aldol condensation of HMF and unreacted saccharides with formyl groups $(-\mathrm{CHO})$ in the presence of acid catalysts $[59,60]$. Thus, the promotion of HMF selectivity can be theoretically achieved by using a biphasic system for transferring the formed HMF from aqueous media to organic phase to suppress HMF rehydration and condensation with saccharides [9].

\subsection{Dehydration of fructose and glucose in 2-butanol $/ \mathrm{H}_{2} \mathrm{O}$ system}

\subsubsection{Dehydration of fructose over Ta and Ta-W oxide in 2-butanol $/ \mathrm{H}_{2} \mathrm{O}$ system}

As far as we know, various organic solvents have been used in biphasic system for conversion of saccharides to HMF.
Among them, solvents with four carbon atoms $\left(\mathrm{C}_{4}\right)$ like 2-butanol were commonly used and showed the highest affinity to HMF, coupled with low water miscibility at the reaction temperature [2-4,32]. Moreover, in our early work we have found that the 2-butanol $/ \mathrm{H}_{2} \mathrm{O}$ catalytic system is effective in conversion of both glucose and sucrose to HMF over $\mathrm{Nb}$ and $\mathrm{Nb}-\mathrm{W}$ oxides catalysts [26]. Thus, further studies of fructose and glucose dehydration were carried out over Ta and Ta-W oxides catalysts with addition of 2-butanol.

The effect of 2-butanol addition on the catalytic performance of fructose dehydration over different $\mathrm{Ta}-\mathrm{W}$ oxides catalysts is shown in Fig. 7. Fig. 7(a) shows that the addition of

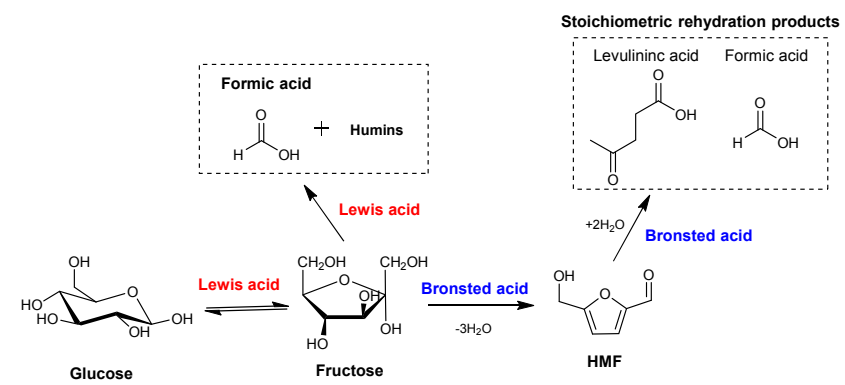

Scheme 3. Proposed pathway responsible for the formation of excess FA. 

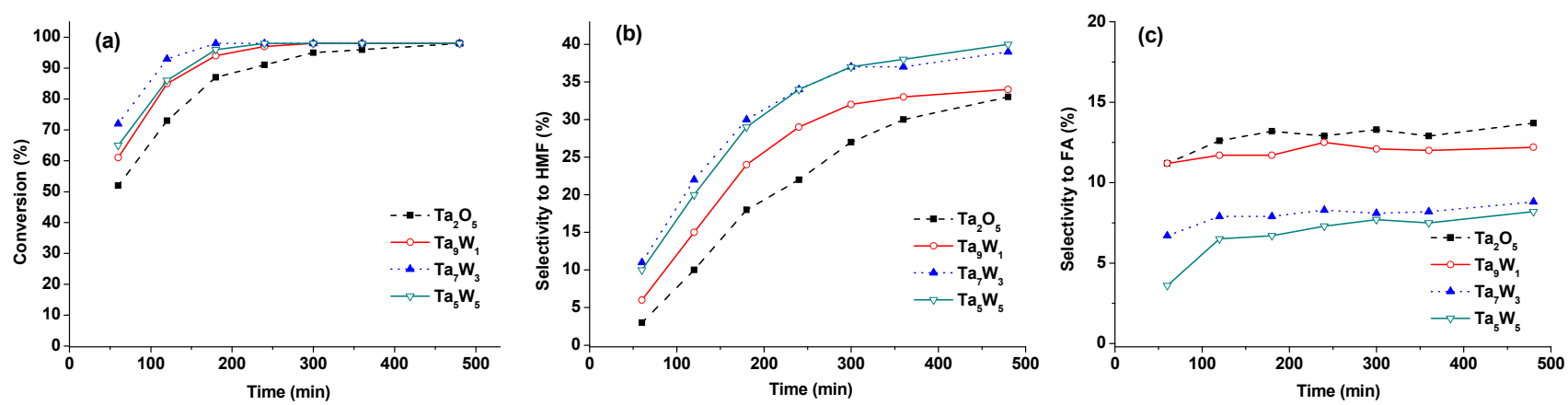

Fig. 7. In the 2-butanol/ $\mathrm{H}_{2} \mathrm{O}$ system the fructose conversion (a), selectivities to $\mathrm{HMF}$ (b) and formic acid (c) versus reaction time over different catalysts. Reaction conditions: $0.1 \mathrm{~g}$ of catalyst, $5 \mathrm{~mL}$ of $2 \mathrm{wt} \%$ fructose, $5 \mathrm{~mL}$ of 2 -butanol $\left(2\right.$-butanol/ $\mathrm{H}_{2} \mathrm{O}=5: 5 \mathrm{v} / \mathrm{v}$ ), $140{ }^{\circ} \mathrm{C}$ with stirring.

2-butanol does not lead to a significant change in fructose conversion over all Ta-W oxides catalysts. However, the HMF selectivity (Fig. 7(b)) over all Ta-W oxides catalysts increases significantly compare to results in aqueous system (Fig. 5(b)). The presence of organic solvent during the fructose dehydration over Ta-W oxides may suppress side reactions which lead to shifting the equilibrium toward the formation of HMF. The trend of HMF selectivity in Fig. 7(b) suggests that high HMF selectivity may be achieved over catalyst with high ratio of Brönsted to Lewis acid sites ( $\mathrm{Ta}_{7} \mathrm{~W}_{3}$ oxide). Notably, higher HMF selectivity is observed over $\mathrm{Ta}_{5} \mathrm{~W}_{5}$ oxide than that over Ta9 $W_{1}$ oxide even though they have the same ratio of Brönsted to Lewis acidity. This result suggests that both the ratio of Brönsted to Lewis acid sites and the strength of Brönsted acid sites affect the selectivity to HMF from fructose dehydration.

Fig. 7(c) shows the effect of 2-butanol on the selectivity of FA over different catalysts. After addition of 2-butanol, the selectivity to FA over all Ta-W oxides catalysts keeps stable with increasing reaction time and is lower than those without 2-butanol addition. However, the selectivity to FA over $\mathrm{Ta}_{2} \mathrm{O}_{5}$ and $\mathrm{Ta}_{9} \mathrm{~W}_{1}$ oxides with high Lewis acid density is relatively high $(>10 \%)$. Thus, the excess formed FA is more likely attributed to direct decomposition of fructose under the role of Lewis acidity rather than rehydration of HMF over Brönsted acid sites. The selectivity to FA over $\mathrm{Ta}_{5} \mathrm{~W}_{5}$ oxide catalyst is lower than the other catalysts in both aqueous system and 2-butanol/ $\mathrm{H}_{2} \mathrm{O}$ system. As $\mathrm{Ta}_{5} \mathrm{~W}_{5}$ oxide has weakest Lewis acidity and strongest Brönsted acidity, the dehydration of fructose to HMF is more preferred than the direct decomposition of fructose to FA. Compared to results of FA selectivity over all Ta-W oxides in aqueous system (Fig. 5(c)), it shows that the addition of 2-butanol results in suppression of side reactions, leading to an increase in the HMF selectivity (Fig. 7(b)).

\subsubsection{Dehydration of glucose over Ta and Ta-W oxide in 2-butanol/ $\mathrm{H}_{2} \mathrm{O}$ system}

The effect of 2-butanol addition on dehydration of glucose to HMF over Ta and Ta-W oxides catalysts has also been investigated. Results in Fig. 8(a) show that the presence of 2-butanol has a significantly beneficial effect in improving the activities of all catalysts. The enhancement of glucose conversion is more pronounced over the catalysts with high ratio of Brönsted to Lewis acid sites compared to the reaction in aqueous system, particularly ca. $15 \%$ increment of glucose conversion observed over the $\mathrm{Ta}_{7} \mathrm{~W}_{3}$ oxide catalyst. This result is possibly due to extraction of formed HMF and other products from reaction substrates by 2-butanol, leading to a shift of equilibrium towards HMF formation from dehydration of formed fructose intermediate over Brönsted acid sites. Besides that, addition of organic solvent also has an effect in increasing the stability of the catalysts by suppressing humins formation, as reported by Ordomsky et al. $[9,15]$, maintaining high activity even with prolonging reaction time. The catalytic activities of Ta-W oxides catalysts in 2-butanol $/ \mathrm{H}_{2} \mathrm{O}$ system increase in the order of $\mathrm{Ta}_{7} \mathrm{~W}_{3}>\mathrm{Ta}_{5} \mathrm{~W}_{5} \sim \mathrm{Ta}_{9} \mathrm{~W}_{1}>\mathrm{Ta}_{2} \mathrm{O}_{5}$, which has the same trend of the ratios of Brönsted to Lewis acid sites.

The same trends of fructose selectivity are obtained in both 2-butanol/ $\mathrm{H}_{2} \mathrm{O}$ system and aqueous system over various Ta-W oxides catalysts (Fig. 8(b) and Fig. 6(b)), where the maximum value of fructose selectivity is achieved at the initial state of the reaction over all Ta-W oxides and then decreases with increasing reaction time, and relatively high fructose selectivity is obtained for catalyst with low ratio of Brönsted to Lewis acid sites. Moreover, the fructose selectivity over Tas $\mathrm{W}_{5}$ oxide is lower than Ta9 $\mathrm{W}_{1}$ oxide which confirms the results in Fig. 6(b), due to the existence of stronger Brönsted acid sites on $\mathrm{Ta}_{5} \mathrm{~W}_{5}$ oxide than that of $\mathrm{Ta}_{9} \mathrm{~W}_{1}$ oxide. However, the selectivity to fructose from glucose isomerization over all $\mathrm{Ta}-\mathrm{W}$ oxides catalysts in 2-butanol/ $\mathrm{H}_{2} \mathrm{O}$ system shows slightly higher values than those in aqueous system. This can be explained by the effect of 2-butanol on suppression of humins formation. Another possibility is that the addition of 2-butanol could reduce the consumption of formed fructose via condensation or polymerization mostly over Lewis acid sites.

Fig. 8(c) shows the selectivity to HMF from glucose dehydration in the 2-butanol $/ \mathrm{H}_{2} \mathrm{O}$ system. Similar to the results in Fig. 7(b), the addition of organic solvent has an effect in increasing the selectivity to HMF, which is also commonly declared or confirmed by the published studies of saccharides dehydration to HMF in biphasic catalytic system $[4,9,14,33,42,61-64]$. The selectivity to HMF from glucose dehydration in 2-butanol/ $\mathrm{H}_{2} \mathrm{O}$ system strongly correlates with the ratio of Brönsted and Lewis acid sites, which increases in the order of $\mathrm{Ta}_{7} \mathrm{~W}_{3}>\mathrm{Ta}_{5} \mathrm{~W}_{5} \sim \mathrm{Ta}_{9} \mathrm{~W}_{1}>\mathrm{Ta}_{2} \mathrm{O}_{5}$. Notably, the selectivity to HMF over $\mathrm{Ta}_{7} \mathrm{~W}_{3}$ oxide catalyst increases with the reaction time and achieves higher value in 2-butanol/ $\mathrm{H}_{2} \mathrm{O}$ system 

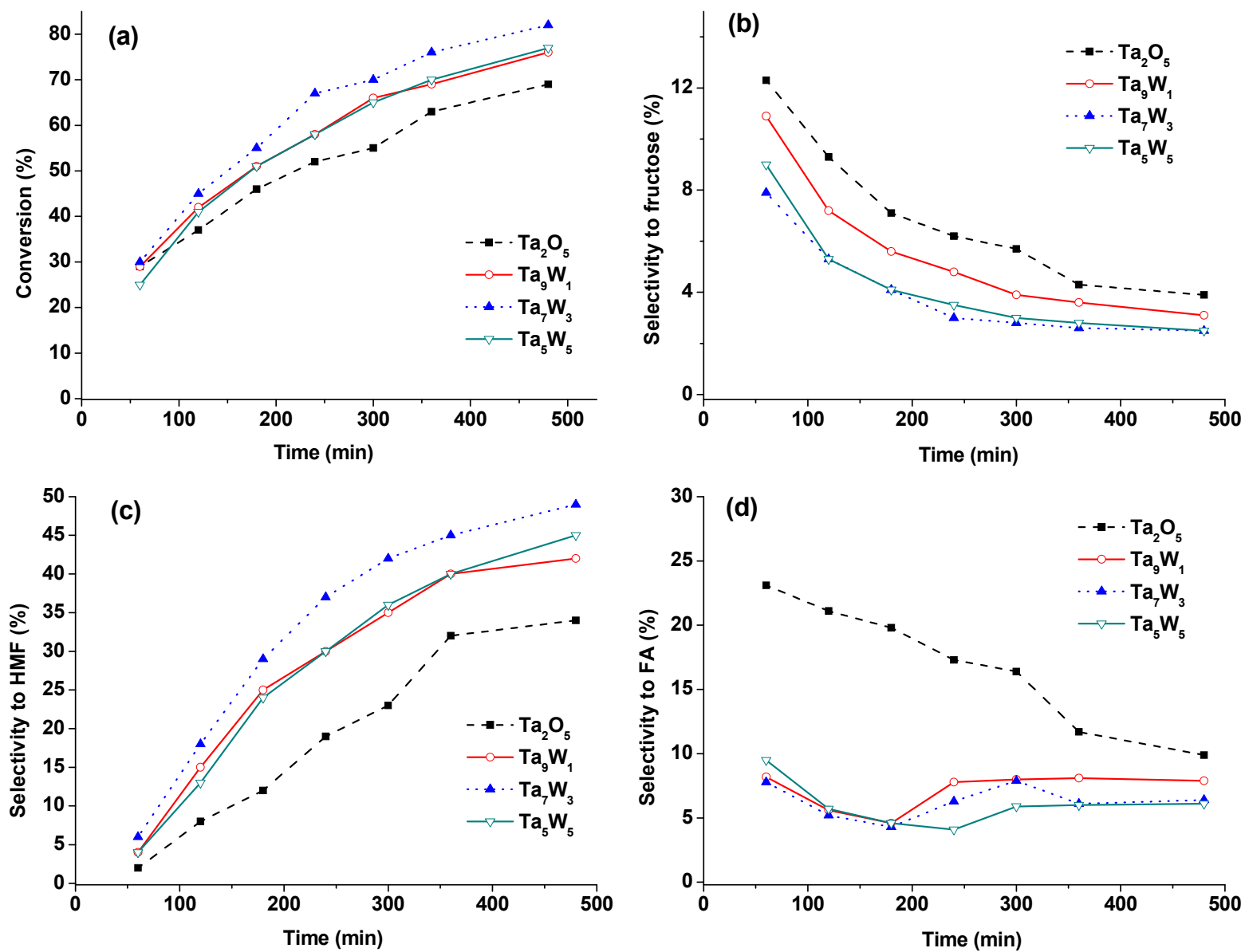

Fig. 8. In the 2-butanol $/ \mathrm{H}_{2} \mathrm{O}$ system the glucose conversion (a), selectivities to fructose (b), $\mathrm{HMF}$ (c) and formic acid (d) versus reaction time over different catalysts. Reaction conditions: $0.1 \mathrm{~g}$ of catalyst, $5 \mathrm{~mL}$ of $2 \mathrm{wt} \%$ glucose and $5 \mathrm{~mL}$ of 2-butanol (2-butanol $\left./ \mathrm{H}_{2} \mathrm{O}=5: 5 \mathrm{v} / \mathrm{v}\right), 140{ }^{\circ} \mathrm{C}$ with stirring.

(49\%) than that in aqueous system (42\%) after 480 min of reaction. Moreover, in both solvent systems with or without 2-butanol, HMF selectivity in glucose conversion are higher than those in fructose conversion over all Ta-W oxides catalysts. The main reason may be due to the relatively low concentration of formed fructose which minimizes side reactions involving fructose [26]. The addition of 2-butanol can effectively decrease the rehydration of HMF over Brönsted acid sites, but show limited effect on suppressing side reactions such as condensation or degradation of hexoses over Lewis acid sites.

The selectivity to FA from glucose dehydration is shown in Fig. 8(d). After 480 min of reaction, the FA selectivity is in the order of $\mathrm{Ta}_{2} \mathrm{O}_{5}>\mathrm{Ta}_{9} \mathrm{~W}_{1}>\mathrm{Ta}_{7} \mathrm{~W}_{3} \sim \mathrm{Ta}_{5} \mathrm{~W}_{5}$. This trend is similar to the results of fructose dehydration over Ta-W oxides catalysts in 2-butanol/ $\mathrm{H}_{2} \mathrm{O}$ system. Therefore, these results are consistent with our previous assumption that the excess formation of FA is attributed to decomposition of fructose over Lewis acid sites.

\subsubsection{Effect of the addition of 2-butanol}

The above results successfully show that the addition of 2-butanol provides an increasing effect on catalytic activity and
HMF selectivity in the reaction of fructose dehydration to HMF, especially for catalyst with high ratio of Brönsted to Lewis acid sites. However, the improvement of HMF selectivity in glucose dehydration by adding 2-butanol is not as significant as that in fructose dehydration, due to retarding the second step of fructose dehydration to HMF. It is well known that the formation of HMF and side products are both highly dependent on the reaction temperature. Thus, the yield of HMF from glucose dehydration is expected to be improved by increasing reaction temperature through extraction of HMF from the reaction mixture and suppressing side reactions involving HMF consumption. To check this assumption, dehydration of glucose to HMF over $\mathrm{Ta}_{2} \mathrm{O}_{5}$ and $\mathrm{Ta}_{7} \mathrm{~W}_{3}$ oxide catalysts at $160{ }^{\circ} \mathrm{C}$ with and without 2-butanol was also investigated (Fig. 9).

Fig. 9(a) shows that the glucose conversion significantly increases over $\mathrm{Ta}_{2} \mathrm{O}_{5}$ and $\mathrm{Ta}_{7} \mathrm{~W}_{3}$ oxide catalysts from $140{ }^{\circ} \mathrm{C}$ to $160{ }^{\circ} \mathrm{C}$ in both aqueous and 2-butanol/ $\mathrm{H}_{2} \mathrm{O}$ system. On the other hand, the selectivity to fructose over $\mathrm{Ta}_{2} \mathrm{O}_{5}$ and $\mathrm{Ta}_{7} \mathrm{~W}_{3}$ oxide catalysts at $160{ }^{\circ} \mathrm{C}$ are lower than those at $140^{\circ} \mathrm{C}$ (Fig. 9(b)). The selectivity to fructose decreases with reaction time, whereas only trace amount of fructose was detected over $\mathrm{Ta}_{7} \mathrm{~W}_{3}$ oxide at $160{ }^{\circ} \mathrm{C}$ in either aqueous system or 2-butanol $/ \mathrm{H}_{2} \mathrm{O}$ system. As the fructose selectivity is strongly 

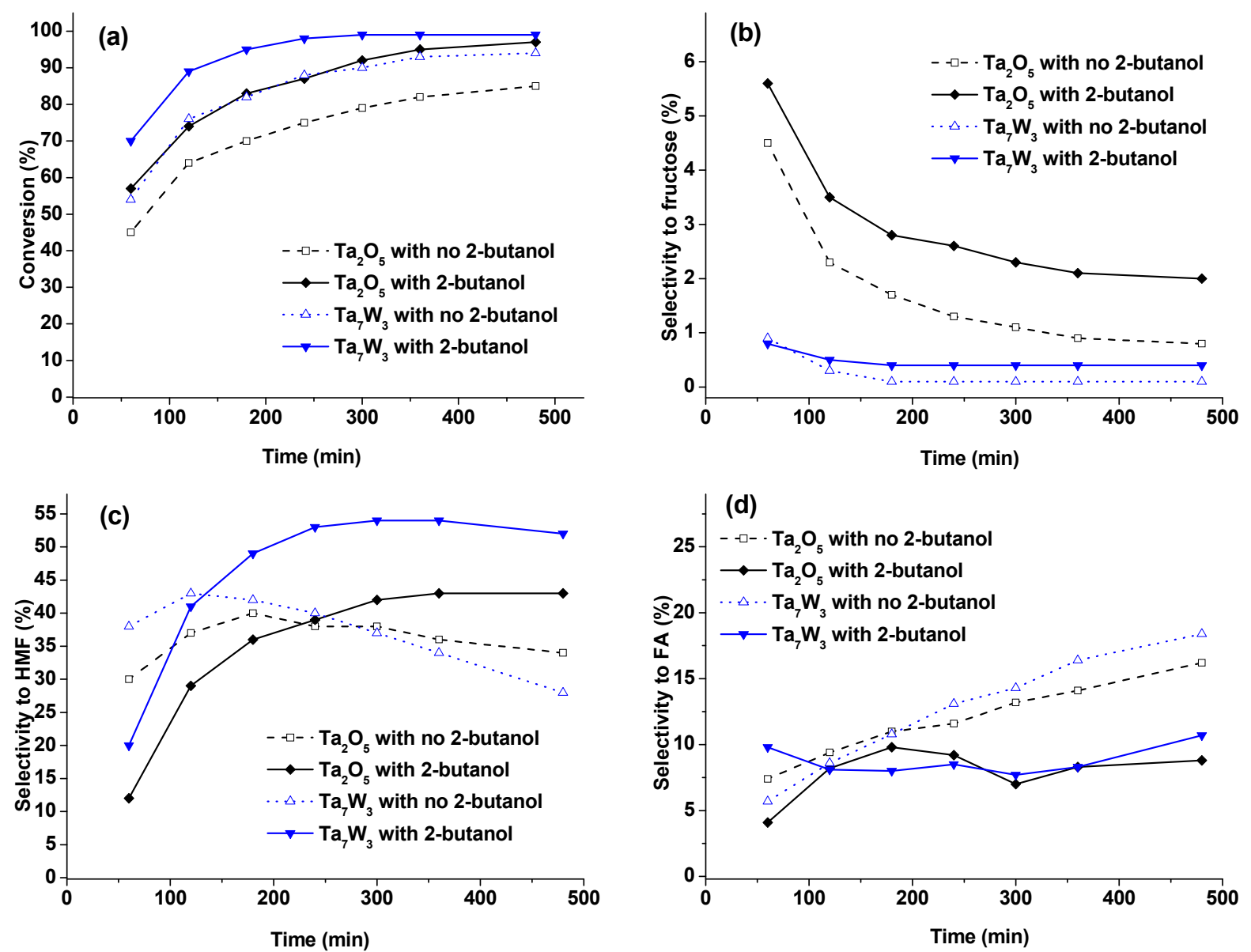

Fig. 9. Effect of 2-butanol on the glucose conversion (a), selectivities to fructose (b), $\mathrm{HMF}$ (c), and formic acid (d) versus reaction time over Ta $\mathrm{O}_{5}$ and $\mathrm{Ta} \mathrm{W}_{3}$ oxide at $160^{\circ} \mathrm{C}$.

dependent on the balance of glucose isomerization and fructose dehydration, this result indicates that the second step of fructose dehydration to HMF enhances more significantly than the first step of glucose isomerization to fructose. Therefore, the preferential fructose dehydration to HMF may be carried out at relatively high reaction temperature.

Fig. 9(c) shows a comparison of HMF selectivity from glucose dehydration over $\mathrm{Ta}_{2} \mathrm{O}_{5}$ and $\mathrm{Ta}_{7} \mathrm{~W}_{3}$ oxide catalysts at 160 ${ }^{\circ} \mathrm{C}$ in aqueous system and 2-butanol $/ \mathrm{H}_{2} \mathrm{O}$ system. The $\mathrm{HMF}$ selectivity for both $\mathrm{Ta}_{2} \mathrm{O}_{5}$ and $\mathrm{Ta}_{7} \mathrm{~W}_{3}$ oxide catalysts in aqueous system exhibit volcano-like curves, which indicate the prevailing occurrence of side reactions of HMF transformation. The HMF selectivity reached a maximum value of $43 \%$ over $\mathrm{Ta}_{7} \mathrm{~W}_{3}$ oxide after $120 \mathrm{~min}$ and $40 \%$ over $\mathrm{Ta}_{2} \mathrm{O}_{5}$ after $180 \mathrm{~min}$. The addition of 2-butanol provides a significant increasing effect in the selectivity of $\mathrm{HMF}$ over $\mathrm{Ta}_{7} \mathrm{~W}_{3}$ oxide, leading to a stabilization of HMF selectivity at $54 \%$. The highest value of HMF selectivity over $\mathrm{Ta}_{2} \mathrm{O}_{5}$ with addition of 2-butanol is $43 \%$, however, no obvious increase was obtained compared to that without 2-butanol (40\%). It suggests that the direct condensation of hexose into humins over Lewis acid sites cannot be effectively suppressed by addition of 2-butanol, leading to relative low HMF selectivity over $\mathrm{Ta}_{2} \mathrm{O}_{5}$ with relatively high Lewis acid density.
Relatively higher FA selectivity are observed for $\mathrm{Ta}_{2} \mathrm{O}_{5}$ and $\mathrm{Ta}_{7} \mathrm{~W}_{3}$ oxide catalysts in aqueous system at $160{ }^{\circ} \mathrm{C}$ (Fig. 9(d)) compared to those at $140{ }^{\circ} \mathrm{C}$. The higher FA selectivity over $\mathrm{Ta}_{7} \mathrm{~W}_{3}$ oxide compared to $\mathrm{Ta}_{2} \mathrm{O}_{5}$ at long reaction time could be explained by the preferential rehydration of HMF over Brönsted acid sites, which corresponds to the decrease of HMF selectivity with reaction time in Fig. 9(c). In addition, the selectivity to levulinic acid over $\mathrm{Ta}_{7} \mathrm{~W}_{3}$ oxide catalyst increases to $6 \%$ after 480 min reaction time (not shown), which is still far lower than the FA selectivity. In the 2-butanol $/ \mathrm{H}_{2} \mathrm{O}$ system, the FA selectivity is in the range of $4 \%$ to $10 \%$ even after $480 \mathrm{~min}$ reaction time, which is lower than that in aqueous system. This result reveals the effect of 2-butanol addition on suppression of FA formation still feasible at high reaction temperature of 160 ${ }^{\circ} \mathrm{C}$.

One advantage of using heterogeneous acid catalysts is their easier recovery from reaction medium than homogeneous acid catalysts. Unfortunately, deactivation of heterogeneous acid catalysts during dehydration of saccharides to HMF was commonly found, due to the deposition of insoluble humins on the surface of catalysts $[9,34,37,65]$. In our case, addition of 2-butanol has already been proved to be effective in increasing the activity of the catalyst and improving the selectivity to HMF by extraction of HMF from aqueous phase which suppresses 


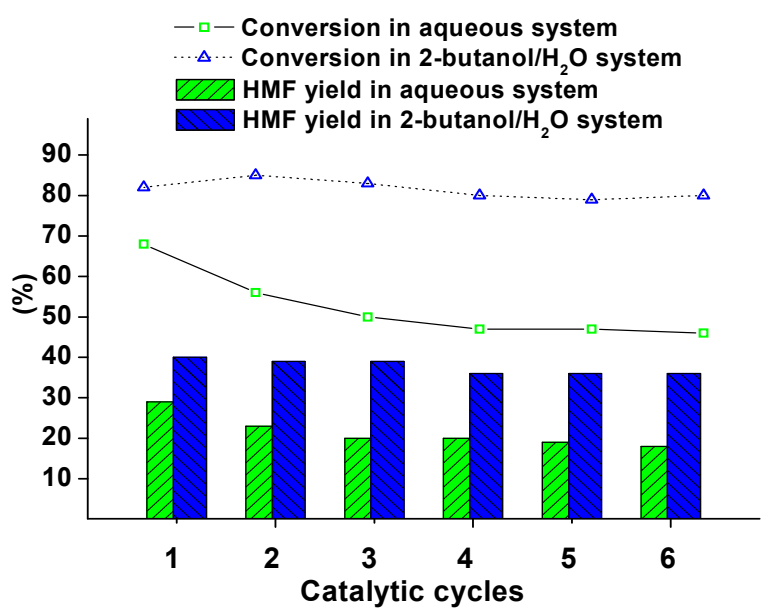

Fig. 10. Effect of 2-butanol on the reusability of $\mathrm{Ta}_{7} \mathrm{~W}_{3}$ oxide for the conversion of glucose into $\mathrm{HMF}$ at $140{ }^{\circ} \mathrm{C}$ for $8 \mathrm{~h}$.

the formation of humins. Thus, to verify the effect of 2-butanol addition in the stability of the catalyst, a recycle test of $\mathrm{Ta}_{7} \mathrm{~W}_{3}$ oxide catalyst for six consecutive runs with and without 2-butanol has been conducted and the results are depicted in Fig. 10. Between each run, the catalyst was simply recovered by washing with $10 \mathrm{~mL}$ of deionized water three times before dry at $120{ }^{\circ} \mathrm{C}$ for $2 \mathrm{~h}$. It can be seen that the activity of $\mathrm{Ta}_{7} \mathrm{~W}_{3}$ oxide catalyst and the yield of HMF in aqueous system continuously decrease, especially for the second cycle with a decrease of glucose conversion from $68 \%$ to $56 \%$ and HMF yield from $29 \%$ to $23 \%$. In contrast, no significant decrease in glucose conversion and HMF yield is observed in the consecutive experiments of dehydration of glucose in the 2-butanol $/ \mathrm{H}_{2} \mathrm{O}$ system. Since the spent catalyst was simply recovered by washing with deionized water before dry at $120^{\circ} \mathrm{C}$ between each run, it suggests that neither carbon deposition nor significant loss of acidity have been occurred. This clearly reveals that the addition of 2-butanol can effectively improve the catalyst stability and results in great reusability of $\mathrm{Ta}_{7} \mathrm{~W}_{3}$ oxide catalyst for the dehydration of glucose to HMF, which is probably due to the suppression of formation of humins and/or the regeneration of active acid sites by removing humins deposed on the surface of the catalyst with organic solvent. Overall, the great reusability of Ta-W oxides and the effect of 2-butanol addition in the activity and stability of the catalyst certainly show a promising catalytic system for carbohydrates conversion.

\section{Conclusions}

A series of mesoporous Ta and Ta-W oxides were prepared by a sol-gel method. The acidity study reveals that the acid strength and the ratios of Brönsted to Lewis acid sites increase with the addition of tungsten in tantalum oxide. In the glucose and fructose conversion to HMF the catalytic activity and selectivity to HMF over all Ta-W oxides catalysts correlate with acid type, density and strength. In general, high sugar conversion and HMF selectivity are achieved over catalyst with relatively high ratio of Brönsted to Lewis acid sites. Strong Brönsted acid sites diminish the HMF selectivity in aqueous medium, due to the increment of side reactions such as unselective dehydration of glucose and rehydration of HMF. Excess formation of FA compared to LA was found over all Ta-W oxides catalysts, duo to the direct decomposition of fructose over Lewis acid sites. The addition of 2-butanol enhances the sugar conversion and the HMF selectivity, especially for catalyst with high ratio of Brönsted to Lewis acid sites, which is caused by the suppression of uncontrollable side reactions and leads to shifting the equilibrium toward the formation of HMF. The highest HMF selectivity of $54 \%$ has been achieved over $\mathrm{Ta}_{7} \mathrm{~W}_{3}$ oxide at 160 ${ }^{\circ} \mathrm{C}$ in 2-butanol/ $\mathrm{H}_{2} \mathrm{O}$ system. Also, the addition of 2-butanol promotes the catalyst stability. Our work may provide useful information to design acid catalyst with balanced ratio of Brönsted to Lewis acid sites and suitable acid strength for conversion of carbohydrate to HMF in an aqueous or biphasic system.

\section{References}

[1] S. P. Teong, G. S. Yi, Y. G. Zhang, Green Chem., 2014, 16, 2015-2026.

[2] R. J. van Putten, J. C. van der Waal, E. de Jong, C. B. Rasrendra, H. J. Heeres, J. G. de Vries, Chem. Rev., 2013, 113, 1499-1597.

[3] A. A. Rosatella, S. P. Simeonov, R. F. M. Frade, C. A. M. Afonso, Green Chem., 2011, 13, 754-793.

[4] Y. Roman-Leshkov, J. N. Chheda, J. A. Dumesic, Science, 2006, 312, 1933-1937.

[5] T. Buntara, S. Noel, P. H. Phua, I. Melian-Cabrera, J. G. de Vries, H. J. Heeres, Angew. Chem., Int. Ed., 2011, 50, 7083-7087.

[6] A. D. Patel, J. C. Serrano-Ruiz, J. A. Dumesic, R. P. Anex, Chem. Eng. J., 2010, 160, 311-321.

[7] R. Kourieh, V. Rakic, S. Bennici, A. Auroux, Catal. Commun., 2013, 30, 5-13.

[8] S. De, S. Dutta, B. Saha, Green Chem., 2011, 13, 2859-2868.

[9] V. V. Ordomsky, J. van der Schaaf, J. C. Schouten, T. A. Nijhuis, J. Catal., 2012, 287, 68-75.

[10] L. Q. Wang, H. Q. Guo, Q. L. Xie, J. G. Wang, B. Hou, L. T. Jia, J. L. Cui, D. B. Li, Appl. Catal. A, 2019, 572, 51-60.

[11] A. H. Motagamwala, K. F. Huang, C. T. Maravelias, J. A. Dumesic, Energy Environ. Sci., 2019, 12, 2212-2222.

[12] C. Shi, Y. Zhao, J. Xin, J. Wang, X. Lu, X. Zhang, S. Zhang, Chem. Commun., 2012, 48, 4103-4105.

[13] X. H. Qi, M. Watanabe, T. M. Aida, R. L. Smith, Jr., Green Chem., 2009, 11, 1327-1331.

[14] Y. J. Pagan-Torres, T. Wang, J. M. R. Gallo, B. H. Shanks, J. A. Dumesic, ACS Catal., 2012, 2, 930-934.

[15] R. Weingarten, Y. T. Kim, G. A. Tompsett, A. Fernandez, K. S. Han, E. W. Hagaman, W. C. Conner, J. A. Dumesic, G. W. Huber, J. Catal., 2013, 304, 123-134.

[16] V. V. Ordomsky, J. Van Der Schaaf, J. C. Schouten, T. A. Nijhuis, ChemSusChem, 2012, 5, 1812-1819.

[17] Q. Xiang, Y. Y. Lee, R. W. Torget, Appl. Biochem. Biotechnol., 2004, 113-116, 1127-1138.

[18] B. F. M. Kuster, Carbohyd. Res., 1977, 54, 177-183.

[19] Y. Roman-Leshkov, M. Moliner, J. A. Labinger, M. E. Davis, Angew. Chem. Int. Ed., 2010, 49, 8954-8957.

[20] H. B. Zhao, J. E. Holladay, H. Brown, Z. C. Zhang, Science, 2007, 316, 1597-1600.

[21] T. F. Wang, Y. J. Pagan-Torres, E. J. Combs, J. A. Dumesic, B. H. 


\section{Graphical Abstract}

Chin. J. Catal., 2020, 41: 1248-1260 doi: S1872-2067(19)63519-9

\section{Dehydration of sugars to 5-hydroxymethylfurfural and non-stoichiometric formic and levulinic acids over mesoporous Ta and Ta-W oxide solid acid catalysts}

Bin Guo, Lulu He, Gangfeng Tang, Li Zhang, Lin Ye, Bin Yue *,

Shik Chi Edman Tsang, Heyong He*

Fudan University, China; University of Oxford, UK

A series of mesoporous Ta and Ta-W oxides have been synthesized and show high catalytic activity and good reusability in the dehydration of sugars to $\mathrm{HMF}$ in 2-butanol $/ \mathrm{H}_{2} \mathrm{O}$ system.

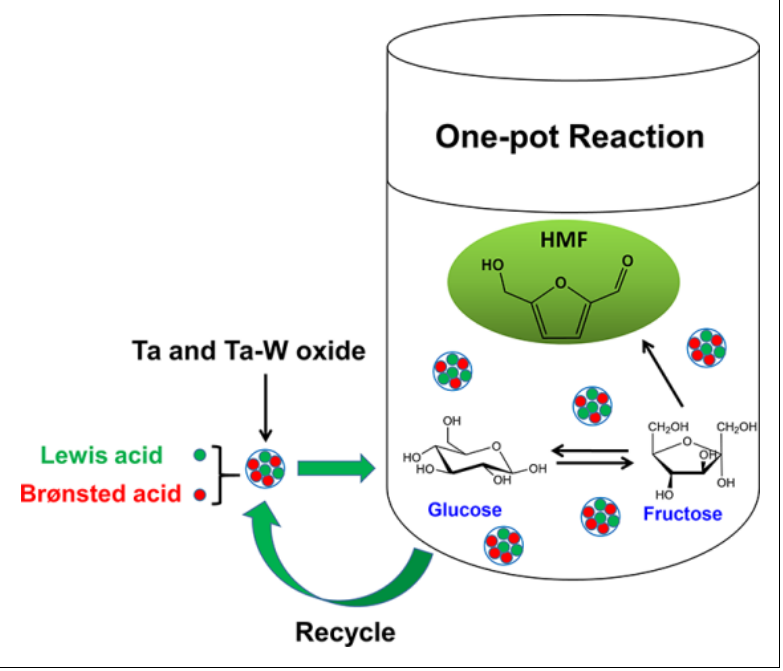

Shanks, Top. Catal., 2012, 55, 657-662.

[22] S. Dutta, S. De, M. I. Alam, M. M. Abu-Omar, B. Saha, J. Catal., 2012, 288, 8-15.

[23] T. Deng, X. Cui, Y. Qi, Y. Wang, X. Hou, Y. Zhu, Chem. Commun., 2012, 48, 5494-5496.

[24] V. Choudhary, S. H. Mushrif, C. Ho, A. Anderko, V. Nikolakis, N. S. Marinkovic, A. I. Frenkel, S. I. Sandler, D. G. Vlachos, J. Am. Chem. Soc., 2013, 135, 3997-4006.

[25] J. Y. G. Chan, Y. G. Zhang, ChemSusChem, 2009, 2, 731-734.

[26] B. Guo, L. Ye, G. F. Tang, L. Zhang, B. Yue, S. C. E. Tsang, H. He, Chin. J. Chem., 2017, 35, 1529-1539.

[27] K. Nakajima, Y. Baba, R. Noma, M. Kitano, J. N. Kondo, S. Hayashi, M. Hara, J. Am. Chem. Soc., 2011, 133, 4224-4227.

[28] J. Guo, S. H. Zhu, Y. L. Cen, Z. F. Qin, J. G. Wang, W. B. Fan, Appl. Catal. B, 2017, 200, 611-619.

[29] G. Qiu, C. P. Huang, X. L. Sun, B. H. Chen, Green Chem., 2019, 21, 3930-3939.

[30] K. H. Peng, X. C. Li, X. H. Liu, Y. Q. Wang, Mol. Catal., 2017, 441, 72-80.

[31] X. C. Li, K. H. Peng, X. H. Liu, Q. N. Xia, Y. Q. Wang, ChemCatChem, 2017, 9, 2739-2746.

[32] F. Yang, Q. Liu, M. Yue, X. Bai, Y. Du, Chem. Commun., 2011, 47, 4469-4471.

[33] I. Jimenez-Morales, M. Moreno-Recio, J. Santamaria-Gonzalez, P. Maireles-Torres, A. Jimenez-Lopez, Appl. Catal. B, 2014, 154-155, 190-196.

[34] I. Jimenez-Morales, A. Teckchandani-Ortiz, J. Santamaria-Gonzalez, P. Maireles-Torres, A. Jimenez-Lopez, Appl. Catal. B, 2014, 144, 22-28.

[35] A. Corma, M. Renz, Chem. Commun., 2004, 550-551.

[36] Q. D. Hou, M. N. Zhen, L. Liu, Y. Chen, F. Huang, S. Q. Zhang, W. Z. Li, M. T. Ju, Appl. Catal. B, 2018, 224, 183-193.

[37] H. Yan, Y. Yang, D. Tong, X. Xiang, C. Hu, Catal. Commun., 2009, 10, 1558-1563.

[38] K. Nakajima, R. Noma, M. Kitano, M. Hara, J. Mol. Catal. A, 2014, $388,100-105$.

[39] R. Noma, K. Nakajima, K. Kamata, M. Kitano, S. Hayashi, M. Hara, J. Phys. Chem. C, 2015, 119, 17117-17125.
[40] T. Ji, Z. Li, C. Liu, X. H. Lu, L. C. Li, J. H. Zhu, Appl. Catal. B, 2019, 243 , 741-749.

[41] P. Ganji, S. Roy, Energy Fuels, 2019, 33, 5293-5303.

[42] V. V. Ordomsky, V. L. Sushkevich, J. C. Schouten, J. van der Schaaf, T. A. Nijhuis, J. Catal., 2013, 300, 37-46.

[43] R. Weingarten, G. A. Tompsett, W. C. Conner, Jr., G. W. Huber, J. Catal., 2011, 279, 174-182.

[44] L. Ye, S. H. Xie, B. Yue, L. P. Qian, S. J. Feng, S. C. Tsang, Y. C. Li, H. Y. He, CrystEngComm, 2010, 12, 344-347.

[45] A. M. Zheng, S. J. Huang, S. B. Liu, F. Deng, Phys. Chem. Chem. Phys., 2011, 13, 14889-14901.

[46] K. Shimizu, T. N. Venkatraman, W. G. Song, Appl. Catal. A, 2002, 224, 77-87.

[47] W. H. Chen, H. H. Ko, A. Sakthivel, S. J. Huang, S. H. Liu, A. Y. Lo, T. C. Tsai, S. B. Liu, Catal. Today, 2006, 116, 111-120.

[48] J. F. Haw, J. H. Zhang, K. Shimizu, T. N. Venkatraman, D. P. Luigi, W. G. Song, D. H. Barich, J. B. Nicholas, J. Am. Chem. Soc., 2000, 122, 12561-12570.

[49] J. H. Lunsford, W. P. Rothwell, W. Shen, J. Am. Chem. Soc., 1985, $107,1540-1547$.

[50] Y. Y. Chu, Z. W. Yu, A. M. Zheng, H. J. Fang, H. L. Zhang, S. J. Huang, S. B. Liu, F. Deng, J. Phys. Chem. C, 2011, 115, 7660-7667.

[51] E. F. Rakiewicz, A. W. Peters, R. F. Wormsbecher, K. J. Sutovich, K. T. Mueller, J. Phys. Chem. B, 1998, 102, 2890-2896.

[52] C. Tagusagawa, A. Takagaki, A. Iguchi, K. Takanabe, J. N. Kondo, K. Ebitani, S. Hayashi, T. Tatsumi, K. Domen, Angew. Chem. Int. Ed., 2010, 49, 1128-1132.

[53] E. I. Ross-Medgaarden, W. V. Knowles, T. Kim, M. S. Wong, W. Zhou, C. J. Kiely, I. E. Wachs, J. Catal., 2008, 256, 108-125.

[54] A. I. Torres, P. Daoutidis, M. Tsapatsis, Energy Environ. Sci., 2010, 3, 1560-1572.

[55] J. N. Chheda, Y. Roman-Leshkov, J. A. Dumesic, Green Chem., 2007, 9, 342-350.

[56] B. Girisuta, L. P. B. M. Janssen, H. J. Heeres, Green Chem., 2006, 8, 701-709.

[57] M. S. Holm, Y. J. Pagan-Torres, S. Saravanamurugan, A. Riisager, J. A. Dumesic, E. Taarning, Green Chem., 2012, 14, 702-706.

[58] V. V. Ordomsky, J. van der Schaaf, J. C. Schouten, T. A. Nijhuis, 
ChemSusChem, 2013, 6, 1697-1707.

[59] M. J. Antal Jr, W. S. L. Mok, G. N. Richards, Carbohyd. Res., 1990, 199, 91-109.

[60] H. E. van Dam, A. P. G. Kieboom, H. van Bekkum, Starch/Stärke 1986, 38, 95-101.

[61] L. Qi, Y. F. Mui, S. W. Lo, M. Y. Lui, G. R. Akien, I. T. Horvath, ACS Catal., 2014, 4, 1470-1477.
[62] J. Tang, L. Zhu, X. Fu, J. Dai, X. Guo, C. Hu, ACS Catal., 2017, 7, 256-266.

[63] S. P. Teong, G. S. Yi, H. Q. Zeng, Y. G. Zhang, Green Chem., 2015, 17, 3751-3755.

[64] Y. Roman-Leshkov, J. A. Dumesic, Top. Catal., 2009, 52, 297-303.

[65] Y. Zhang, J. J. Wang, J. W. Ren, X. H. Liu, X. C. Li, Y. J. Xia, G. Z. Lu, Y. Q. Wang, Catal. Sci. Technol., 2012, 2, 2485-2491.

\title{
氧化钽及钽铇复合氧化物固体酸催化己糖脱水制备5-羟甲基糠醛以及 非等计量比的甲酸和乙酰丙酸
}

\author{
郭 斌, 贺露露 ${ }^{\mathrm{a}}$, 唐钢锋 ${ }^{\mathrm{a}}$, 张 丽 ${ }^{\mathrm{a}}$, 叶 林 ${ }^{\mathrm{a}}$, 岳 斌, ${ }^{\mathrm{a}}$, 曾适之 ${ }^{\mathrm{b}}$, 贺鹤勇, ${ }^{\mathrm{a}, \#}$ \\ 复旦大学化学系, 能源材料化学协同创新中心上海市分子催化与功能材料重点实验室, 上海200433, 中国

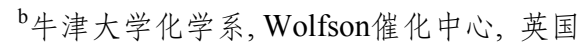

\begin{abstract}
摘要: 5-羟甲基糠醛(HMF)是最具应用前景的平台化合物之一, HMF制备的研究越来越成为热点, 并且已经取得了令人瞩 目的研究成果. 尽管如此, 在现阶段利用固体酸催化剂催化碳水化合物制备HMF的研究仍然面临许多挑战, 以葡萄糖为原 料制备HMF时产物选择性普遍较低. 因此, 合成制备高活性催化糖类化合物脱水制HMF的固体酸催化剂, 并且研究固体酸 催化剂表面酸性质比如酸密度、酸强度以及Brönsted/Lewis酸比值等对糖类化合物制HMF反应中各反应产物选择性的影 响, 对新型高效催化剂的开发设计具有重要意义.

本文通过溶剂挥发自组装法合成了一系列介孔 $\mathrm{Ta} \mathrm{T} \mathrm{Ta}-\mathrm{W}$ 氧化物固体酸催化剂, 并用于催化果糖和葡萄糖脱水制备5羟甲基糠醛. 以三甲基膦(TMP)为探针分子, 利用 ${ }^{31} \mathrm{P}$ 固体核磁共振谱技术表征催化剂表面酸性质, 考察复合金属氧化物固 体酸催化剂酸量、酸强度以及酸类型对催化果糖和葡萄糖制备HMF反应性能的影响, 为高效催化剂的设计提供一定的理论 指导. 另外, 我们还通过引入2-丁醇构建有机溶剂/水体系, 考察有机溶剂对葡萄糖脱水制HMF反应中所用催化剂活性和产 物选择性的影响. ${ }^{31} \mathrm{P}$ 固体核磁共振技术表征样品的酸性质发现, 随着 $\mathrm{W}$ 掺杂量的增加, 系列 $\mathrm{Ta}$ 及 $\mathrm{Ta}-\mathrm{W}$ 氧化物的酸强度和 Brönsted/Lewis酸量比值逐渐增加. 催化反应结果表明, 以介孔 $\mathrm{Ta}$ 及 $\mathrm{Ta}-\mathrm{W}$ 复合氧化物为催化剂时, 果糖和葡萄糖脱水制 $\mathrm{HMF}$ 反应的催化活性和HMF选择性与所用催化剂的酸量、酸类型和酸强度有关. 介孔 $\mathrm{Ta} \mathrm{K} \mathrm{Ta}-\mathrm{W}$ 复合氧化物催化剂表面的 B/L比值越高, 催化反应过程中的已糖转化率也越高, HMF选择性也普遍越高. 具有较高Brönsted酸强度的催化剂在水溶液 中更易降低HMF产物选择性, 归结于HMF的再水解和葡萄糖的非选择性脱水等副反应. 实验结果发现, 产物甲酸(FA)的选 择性远高于乙酰丙酸(LA), 说明过量FA很可能来自果糖在Lewis酸位上的分解. 2-丁醇的引入能够提高己糖转化率和HMF 选择性, 并且在 $\mathrm{B} / \mathrm{L}$ 比值越高的催化剂上提升的效果越显著. 其中, $\mathrm{Ta}_{7} \mathrm{~W}_{3}$ 氧化物为催化剂时, $\mathrm{HMF}$ 选择性最高可达 $54 \%$, 并 且该催化剂具有良好的催化稳定性, 这主要是因为2-丁醇的加入能够有效地抑制反应中胡敏素等聚合物的生成, 防止后者 在催化剂表面附着导致催化活性降低, 进而提高了催化剂在催化反应中的稳定性.
\end{abstract}

关键词: 葡萄糖; 果糖; 5-差甲基糠醛; 固体酸; 氧化钽; $\mathrm{Ta}-\mathrm{W}$ 氧化物

收稿日期: 2019-11-28. 接受日期: 2019-12-27. 出版日期: 2020-08-05.

*通讯联系人. 电话: (021)31243916; 电子信箱: yuebin@fudan.edu.cn

\#通讯联系人. 电子信箱: heyonghe@fudan.edu.cn

基金来源：国家自然科学基金(21673046, 91645201).

本文的电子版全文由Elsevier出版社在ScienceDirect上出版(http://www.sciencedirect.com/science/journal/18722067). 